\title{
The Impact of Human Resources Management in SMEs on the Republic of Kosovo
}

\author{
Shpresa Bajrami PhD.c \\ State University of Tetova
}

\begin{abstract}
In this paper we will talk about the impact of human resources management in the SMEs growth in Kosovo. Human resources management is the innovation and creativity that employees have for their organization. Human Resources play an important role nowadays in a modern and dynamic economy. The failure of an implementation of good HR strategy strongly affects society, if we consider the lost opportunities and the resources consumed. It is therefore necessary to better understand the importance of HR development for the global economy, something that we will try to highlight in this paper.For the company to succeed in the business environment and in their industry they have to be very creative and innovative. Companies have to come up with the new products, marketing strategy and new ventures etc. Unemployment rate in Kosovo is very high around $40 \%$ comparing to the young generation that enter the working market every year. So, SMEs are considered very essential in smoothing this unemployment rate and give this generation new possibilities on showing their working potential. Furthermore, finding work for this generation we also have impact on the so called brain drain, which is a concerning issue for Kosovo. So, SMEs are not having impact only in the economic growth but also in the aspect of keeping youth and their potential inside the country.
\end{abstract}

Keywords: Human resources management (HRM), SMEs, innovation, creativity, society, global economy, new ventures.

DOI: $10.7176 / \mathrm{RJFA} / 10-2-10$

\section{Introduction}

In the economy of Republic Kosovo, as well as on the business practices of developed countries, SMEs throughout the last decade have had a new and powerful mission and role in the accelerated economic development of the country. These business entities are presented as the main source of job creation and income generation both in the central budget and at the local (municipal) level, showing a rapid socio-economic revitalization in the above mentioned period. Thus, successively, the issue of employment in existing and new private enterprises is marking a permanent increase, undergoing structural changes within the enterprise. All these qualitative changes within the overall socio-economic potential of Kosovo have resulted in the number of commercial enterprises and also increased participation of production-oriented enterprises, which, enable the expansion of the material base of businesses and their contribution to the development of the country's economy.

In one organization we have three types of resources: goods and services, financial, and human resources. Out of these three resources of the most essential enterprise are human resources, because without human resources, those assets will not be multiplied, so this asset of the enterprise in the future will increase the value of the entire enterprise.

With access to growth and development of the SMEs we see that Human Resources should occupy a special place and have a special care in the enterprise, because using methods and using tools that make our company employees feel good and will to evaluate the company as their property, they will give the best results progressively.

By using these methods and tools, we as an enterprise motivate our company's employees to do their best for undertaking and achieving the best results.

The management of human resources requires that in the enterprise or any other institution to plan human resource, to make a recruitment, selection, organize employees development (training, preparation), selection, adaptation at work and so on.

Human resources means a competitive aggressiveness, problem solving, reactiveness and innovativeness within a corporation. It refers to the employees' initiative to undertake something new without them being requested to do so. ${ }^{1}$

The concept of Human Resources is about seeing individuals working within large corporations and SMEs leverage their deep industry knowledge and understanding of the business gaps within their sectors to create profitable companies. ${ }^{2}$

Government officials should take stimulating actions to encourage new entrepreneurs to take the risk on creating new enterprises. Also, there should be law enforcement for the right in property and encourage a

\footnotetext{
${ }^{1}$ Intrapreneurship; Conceptualizing entrepreneurial employee behavior, Jeroen de Jong, Sander Wennekers 2007/2008

${ }^{2} \mathrm{http} / /$ www.twentyfoursevennews.com/headline/intrapreneurship-serves-as-a-catalyst-to-growth/
} 
competitive market.

Human Resources is very important for Kosovo's companies since we know that Kosovo is the newest country in the Europe and is in development process. The global economy has significantly grown with the furthering of the process of globalization which has resulted in a global financial, industrial and business system.

Liberalization of trade, by implementing free-market policies and lowering trade barriers together with the creation of an international framework that serves as a promoting and safeguarding system, primarily seen in the international agreements on trade and international institutions, have led to rapid growth in trade and investment. Economic opening of national borders has unlocked the potential for further growth by increasing the productive capacities and opportunities for investments.

Most of the companies in Kosovo are SME companies. This tells us that its very big number of entrepreneurs compare with intraperneureship, which are not developed. This comes as reasons because there are very few big companies or corporates that gives opportunities to the employees to explore their knowledge by taking initiatives for the innovation and new product development.

In this paper we will see the status of the Human resources development in Kosovo's companies and impact of having good SMEs in the economy growth.

\section{Research Methodology}

The research will be conducted by collecting data from available of the secondary sources such as surveys, statutes, cases, books, encyclopedia, journals, seminar, conference papers and internet materials.

\section{Research hypotheses}

Hypotheses that will be tested:

Ho-basic hypothesis: How much higher is the integration of human sources activities and those of strategic management, the higher is the increase in property firms and economic development of the country.

Hi 1: Human resources regarding the employee integration help companies and specially SMEs reduce chances of failure,

Hi 2: Growing of SMEs, small and medium affects in the reducing the unemployment rate (Orientation of the firms toward competitive growth by investing in HR development) Hi 3: Growth of SMEs towards maximization effects of the export.

\section{Human resources regarding the employee integration helps companies and specially SMEs reduce chances of failure}

The employee integration helps companies and specially SMEs to increase the successfulness and reduce the chances of failure. In Kosovo most of the companies do not have HR department and they are more into copy past idea rather than coming up with new ideas. Innovation and creativity is something that helps companies to come up with new ideas of investments like investing in the new idea of products, exploring the market and predicting the future risk.

Human Resources is an example of employees' motivation, which through their creative spirit is indispensable for their company, thus becoming a key component of this phenomenon. By stimulating the creativity of employees, the company can achieve its objectives, to be innovative and to renew itself from a strategic point of view. A number of studies show that employees who have a creative spirit are the basis of a competitive and successful company. If employees demonstrate creative power at their workplace, if they come up with new ideas that can further be valuable for future products and processes, they help to increase the possibility that other employees feel motivated to come up with new ideas.

Therefore, in order to be updated with the current changes and to be concurrent in the market they need to be innovative and creative regarding the business ideas. Competitiveness is one thing that makes company suffer and maybe fail in the future. In Kosovo companies are more into copy of business ideas than developing their innovations and creativeness.

Innovation labs are very needed in Kosovo because in order to help SME companies to get bigger and to explore their products oversees they need to be very creative in order to be competitive in the market and specially in the foreigner markets. In most of the SMEs in Kosovo when we see the statement of financial positions we understand that income that they possess is almost same with other companies and they grow until to the one stage and they get stuck there. So, for SMEs to growth their income and to become bigger and bigger they need to implement the Human Resources by integrating employees in the innovation, creativity and decision making processes.

Growing of SMEs, small and medium helps in the reducing the unemployment rate (Orientation of the firms toward competitive growth by investing in HR development) Unemployment rate in Kosovo is very high around 40\% comparing to the young generation that enter the 
working market every year. So, SMEs are considered very essential in smoothing this unemployment rate and give this generation new possibilities on showing their working potential. Furthermore, finding work for this generation we also have impact on the so called brain drain, which is a concerning issue for Kosovo. So, SMEs are not having impact only in the economic growth but also in the aspect of keeping youth and their potential inside the country.

Evidence proving that in Europe and everywhere in the world most of the businesses are SMEs. Whereas regarding Kosovo, the data show that $99.97 \%$ are SMEs and regarding the employment rate $81 \%$ of the total employees are part of SMEs. Average employees for a micro enterprise workers is 1:57 (See table below)

\begin{tabular}{|c|c|c|c|c|c|c|c|c|c|c|}
\hline 2007 & & & 201 & & 20 & & 201 & & 20. & \\
\hline Nr. & & $\%$ & Nr. & $\%$ & Nr. & $\%$ & Nr. & $\%$ & Nr. & $\%$ \\
\hline Micro enterprises & $\begin{array}{l}6,744 \\
98.40\end{array}$ & 96.79 & 8,242 & 97.50 & 9,798 & 97.48 & 9,420 & 98.00 & 9,919 & \\
\hline Small enterprises & $\begin{array}{l}178 \\
1.38\end{array}$ & 2.55 & 160 & 1.89 & 215 & 2.14 & 165 & 1.72 & 139 & \\
\hline Medium enterprises & $\begin{array}{l}40 \\
0.19\end{array}$ & 0.57 & 43 & 0.51 & 31 & 0.31 & 21 & 0.22 & 19 & \\
\hline Total SMEs & $\begin{array}{l}6,962 \\
99.97\end{array}$ & 99.91 & 8,445 & 99.91 & 10,044 & 99.93 & 9,606 & 99.94 & 10,077 & \\
\hline Large enterprises & $\begin{array}{l}\mathbf{6} \\
\mathbf{0 . 0 7}\end{array}$ & 0.09 & 10 & 0.11 & 8 & 0.10 & 8 & 0.07 & 9 & \\
\hline Total & $\begin{array}{l}6,968 \\
100 \%\end{array}$ & $100 \%$ & 8,453 & $100 \%$ & 10,051 & $100 \%$ & 9,612 & $100 \%$ & 10,080 & \\
\hline
\end{tabular}

According to the table, from 2013 until 2016 the number of SMEs has been increased with a rate of $20 \%$ every year, and the general increase in this last five years was around $35 \%$, but there is not a certain number of the SMEs that have been closed or bankrupted. Taking into account the number of people that enter the working market every year, it is estimated that Kosovo needs a real economic growth at least $7 \%$.

\begin{tabular}{|l|c|l|c|l|}
\hline \multirow{2}{*}{ Enterprise Size } & \multicolumn{2}{|c|}{ No of enterprises } & No & of \\
\cline { 2 - 5 } & Nr. & $\%$ & Nr. & $\%$ \\
\hline Micro enterprises (1-9 employees ) & 109,800 & 98.4 & 185,129 & $64 \%$ \\
\hline Small enterprises (10 - 49) & 1,508 & 1.4 & 24,877 & $9 \%$ \\
\hline Medium enterprises (50 - 249) & 224 & 0.2 & 22,411 & $8 \%$ \\
\hline Total Nr of SMEs & 11,532 & $99.99 \%$ & 232,417 & $80 \%$ \\
\hline Large enterprises (above 250) & 58 & 0.1 & 55,658 & 20 \\
\hline TOTAL & 11,590 & $100 \%$ & 288,075 & $100 \%$ \\
\hline
\end{tabular}

Source: Agency of Statistics of Kosovo (ASK)

How many workers are employed by watching the opening number of SMEs. According to the table, in 2013 the number of employers by the SMEs was 64\% in all enterprises, and in 2016 this was increased in $80 \%$, where $19 \%$ of this difference were employed in big enterprises. ${ }^{1}$

Growth of SMEs towards maximization effects of the export. (The impact of the intraprenuarship in Kosovo's economy)

Human Resources helps SME companies to grow up and after a while to become corporate or big manufacturing. In Kosovo number of corporates is very small compared with SME companies. Kosovo's economy is in deficit as import is higher than export, this tells us that most of the goods we export from outside because the production level in Kosovo is very small.

The Kosovo Agency of Statistics (KAS) has published data on the flows of export and import of goods for the month of April 2016. Data from Kosovo Foreign Trade show a higher trade deficit of 227.6 million Euros, or 16.1\% in April 2016 compared to the 196.1 million Euro deficit of the same period of 2015. Exports covers imports by $9.2 \%$.

Exports of goods in April 2016 amounted to Euro 23.0 million, while imports amounted to Euro 250.7 million, a decrease of $-16.9 \%$ for exports and an increase of $12.0 \%$ for imports compared to the same period of 2015.

According to the data of the main export groups: $34.3 \%$ of exports are made up of base metals and articles thereof; $16.5 \%$ are mineral products; $13.5 \%$ consists of plastics, tires and articles thereof; $10.0 \%$ consists of prepared meals, beverages and tobacco; $5.8 \%$ consists of various manufactured articles; $4.2 \%$ consists of leather and articles thereof; $3.5 \%$ consists of plant products; $2.9 \%$ ) are made up of textiles and articles, etc.

\footnotetext{
${ }^{1}$ Task forca per integrim evropian, Material per diskutim per fushen e industrise dhe NVM-ve, Nentor 2016.
} 
Meanwhile, according to the data of main groups for import: $12.6 \%$ of imports comprise prepared meals, beverages and tobacco; $12.3 \%$ consists of basic metals and articles thereof; $11.7 \%$ consists of machinery, mechanical and electrical equipment; $10.0 \%$ are mineral products; $9.5 \%$ consists of chemical industry products; $7.7 \%$ consists of plastics, rubber and articles thereof; $7.2 \%$ constitute the means of transport; $5.5 \%$ consist of plant products, etc.

So, based on this we can see that import is very high when we compare with export in Kosovo and this tells us that number of corporates or manufacturing that exist is very small. By implementing intraprenurship more in Kosovo can help a lot to increase the number of the employees and at same time increase the export because SMEs in Kosovo are more into copping each other than coming up with their ideas. ${ }^{1}$

\section{Conclusion and recommendations}

Based on the information above we can agree that human resources development plays an important role nowadays in a modern and dynamic economy of the country and specially in Kosovo. The failure of an HR strongly affects society, if we consider the lost opportunities and the resources consumed. It is therefore necessary to better understand the importance of Human Resources for the global economy.

Employees / intrapreneurs can use their creative and innovative ideas to create new products, processes or new divisions for their company having full support from the company and the availability of the necessary resources.

Quantity and quality of human resources allocated to innovative initiatives are crucial to the success of creative ideas. Incentives for generating creative ideas help employees to focus their efforts on product development projects and innovation objectives. This is influenced by how risk-taking is managed, ideas are evaluated, mistakes are spared, changes are discussed, communication is supported, the identification of ideas is done, reward systems are established, etc. ${ }^{2}$

Therefore, in Kosovo there is very much needed for employees to be innovative and creative into creating ideas. Another thing that needs to be done for companies in order to participate in the global market they have to have the employee integration, where employees can participate in the product development, lunching and decision making.

Strategy of the human resources and management needs to change in Kosovo's companies where the owner of the company does not need always to be the part of the working staff and specially where most of the decisions come from that person, which most of the time is not something that is new in the market but something that is already in the market and they think that they can compete with the competitors.

At the end, I would really recommend to all the companies considering SMEs and big cooperates in Kosovo to start implementing more the HR activities because only by doing so we can increase our profit and we can participate in the global market which can help us to reduce the import and at same time to increase the export and by doing so we can increase the economy of the country.

\section{References}

Richard L. Daft (2008), Organizational Theory and Design, South-Western Cengage Learning, 403-420

Jeroen de Jong, Sander Wennekers (2007)Human Resources; Conceptualizing entrepreneurial employee behavior, http://www.twentyfoursevennews.com/headline/Human Resources-serves-as-a-catalyst-togrowth/

Task forca per integrim evropian, Material per diskutim per fushen e industrise dhe NVM-ve, Nentor 2012.

Agjencia e Statistikave të Kosovës, Seria 3: Statistikat Ekonomike, Statistikat e Tregtisë së Jashtme, Nëntor 2013 http://www.doktoratura.unitir.edu.al/wp-content/uploads/2014/01/Doktoratura-Enver-H.-KrasniqiFakulteti-Ekonomik-Departamenti-i-Manaxhimit.pdf

Martin, EC \& Terblanche, F (2003), 'Building organisational culture that stimulates creativity and innovation', European Journal of Innovation Management, Vol.6, No.1, pp.64-74

Fund,E.I.(2016,0404). Gjetur 04 04, 2016, nga eif: http://www.eif.org/what_we_do/resources/wbedif/ group, w. b. (2016, march). Doing Business. Gjetur 03 03, 2016, nga Doing Business: http://www.doingbusiness.org/data/explore economies/kosovo Hood, N. and Young, S. (1979). The Economics of Multinational Enterprise. Longman Group Limited.

E. U. (2014.). Stabilisation and Association Agreement between the European Union and Kosovo. Prishtine: Governance of Kosovo \& EU. Kosovo, G. o. Law on Ratification of the Framework Agreement between the Government of the Republic of Kosovo and the European Investment Bank regulating the activities of the European Bank for Investment in Kosovo. Prishtine: Governance of Kosovo \& EU. Kosovo, I. o. (September 2014).

Progress Raport of the year 2014 to Europian Comision for Kosovo. Prishtine: Europian Comision for Kosovo .

\footnotetext{
${ }^{1}$ Agjencia e Statistikave të Kosovës, Seria 3: Statistikat Ekonomike, Statistikat e Tregtisë së Jashtme, Nëntor 2013

${ }^{2}$ Martin, EC \& Terblanche, F 2003, 'Building organisational culture that stimulates creativity and innovation', European Journal of Innovation Management, Vol.6, No.1, pp.64-74
} 
Brada, Kuta and Yigit (2006). The Effects of Transition and Political Instability on Foreign Direct Investment Inflows.

Price, A. (2007): Human resource management in a business context, Thomson Learning, London 